\title{
FORMATION OF WATER REGIME DURING IRRIGATION BY LIVESTOCK WASTE
}

\author{
Vladimir Zhelyazko ${ }^{1}$, Victor Kopytowski ${ }^{1}$, Yuri Mazhaysky ${ }^{2}$, Olga Chernikova $^{3}$ \\ ${ }^{1}$ Belarusian State Agricultural Academy, Belarus; ${ }^{2}$ Ryazan State University \\ named after S.A. Yesenin, Russia; ${ }^{3}$ Academy of Law Management \\ of the Federal Penal Service of Russia, Russia \\ zhaliazka@mail.ru,prorektor.axr@mail.ru,mail@mntc.pro, chernikova_olga@inbox.ru
}

\begin{abstract}
The effect of long-term irrigation by livestock waste on the fertility of sod-podzolic soil has been studied in irrigation fields since 1999. At the same time, it has been found that as a result of fertilizer irrigation by livestock waste, the reliability of the specialized water rotation and amelioration system increases significantly during conducting agromeliorative practices that have a beneficial effect on the hydrological regime of irrigated lands. Depending on the moisture supply of the growing season during irrigation by livestock waste with an average nitrogen rate of $280 \mathrm{~kg} \cdot \mathrm{ha}^{-1}$, in order to create an optimal water regime, it was necessary to carry out from three to six irrigations with one-time norms of $18-25 \mathrm{~mm}$ in different years. At the same time, irrigation norms ranged from 59-135 mm. Over the years of research, the water consumption of perennial grasses averaged $488.7 \mathrm{~mm}$ in control without irrigation, and 491-493.3 $\mathrm{mm}$ during watering by waste, depending on the conducted argomeliorative measures. The greatest total water consumption of perennial grasses was noted in the variant of irrigation by livestock waste against the background of drainless drainage combined with deep cultivation and the application of straw. Compared to the control without irrigation in irrigated variants, the total water consumption of perennial grasses was on average 85.2-90.3 $\mathrm{mm}$ or $21.1-22.4 \%$ more. The water consumption of perennial grasses obtained by the calculation method for the sum of air humidity deficits using bioclimatic coefficients was $496.3 \mathrm{~mm}$ on average over the years of research and differed from the actual water consumption obtained in the experiment by no more than 5-10\%. On the basis of many years of research, it can be concluded that it is recommended to carry out deep cultivation $(60 \mathrm{~cm})$ and apply straw at a rate of $4.0 \mathrm{t} \cdot \mathrm{ha}^{-1}$ to improve the water regime and agrophysical properties of soil during using livestock waste in irrigation fields. The effectiveness of agromeliorative practices has been observed for 5-6 years.
\end{abstract}

Keywords: livestock waste, irrigation, water consumption, agromeliorative practices, drainless drainage.

\section{Introduction}

For the Republic of Belarus, one of the priorities is the development of the livestock sector of the agricultural and industrial complex, which is necessary to ensure the country's food security and increase its export potential on the world food market. However, the production of livestock products on an industrial basis has created a serious environmental problem associated with the utilization of large volumes of manure runoff. Belarus livestock complexes produce 19.4 million $\mathrm{m}^{3}$ of runoff annually $[1 ; 2]$.

The solution to this problem in our Republic was mainly through the construction of specialized reclamation systems, where manure runoff is used for fertilizing irrigation of forage crops. However, many years of experience in operating such systems has shown that this technology is characterized by a number of weaknesses. There is an excessive accumulation of biogenic elements and pollutants in the soil, especially on low terrain elements. Agricultural landscapes have appeared, where technogenic soil contamination with heavy metal compounds is of particular concern. Water resources, as the most dynamic natural formations, are also subject to pollution [3; 4].

Currently, various technologies are used for the utilization and detoxication of livestock waste. One of them is the use of effluents for fertilizer irrigation of crops. To implement this technology, specialized water rotation and amelioration systems were built at the complexes. The experience of their operation shows that environmental safety is not ensured even on perfect water rotation systems.

First of all, this refers to the individual elements of the drainage, which should intercept contaminated surface and subsurface runoff and divert it to storage ponds with subsequent use for irrigation. Agromeliorative practices are usually applied to reduce the volume of waste. This can improve the water-air regime of the soil and increase crop yields. Drainless drainage is of practical interest in regulating the water regime of soil during watering by livestock waste. It allows the accumulation of pollutants from livestock waste. However, such a measure is not provided on specialized amelioration systems with using livestock waste. 
At the same time, experience gained both in our country and abroad shows that the disposal of wastewater and its purification on agricultural irrigation fields favorably affects crop yields, increases the soil fertility and reduces the cost of irrigation water. The beneficial effect of the use of wastewater and its sludge is noted in the works of Zakkour P.D., D.P. Gostishchev, A.V. Shuravilin, Gaterell M.R., Griffin P., Ternes T.A., Bonerz M., Islam M.S., Mooers H.D., Alexander Jr. E.C., Lubello C., Gori R., Nicese F.P., Skousen, J., Clinger C. [6, 7, 8, 9, 10, 11].

Therefore, the research was conducted on topical issues of studying the impact of drainless drainage, agromeliorative practices (soil cultivation, deep loosening) and the application of straw on the amelioration system with using livestock waste, which should provide improved water regime, agrophysical soil properties and increase grass yields while reducing pollution of environment.

\section{Materials and methods}

Experimental research, production verification and implementation of the results were carried out in 1999-2005, 2009-2010 and 2014 on the experimental site in RAUE SHC "Zadneprovsky" in Orsha district of Vitebsk region. This farm has a pig-breeding complex, designed for growing and fattening of 54 thousand heads of pigs per year. Manure is removed from livestock buildings hydraulically. As a result of this, the annual output of manure waste ranges from 303.4 to 498.4 thousand $\mathrm{m}^{3}$ depending on the number of livestock. The field experience was laid to study the joint effect of agromeliorative practices and drainless drainage during fertilizer irrigation. The experimental scheme included the following options:

1. without irrigation by waste and agromeliorative practices (absolute control);

2. irrigation by waste without amelioration measures (control);

3. waste irrigation + drainless drainage;

4. waste irrigation + drainless drainage in combination with soil cultivation by $30 \mathrm{~cm}$;

5. waste irrigation + drainless drainage in combination with loosening to a depth of $60 \mathrm{~cm}$;

6. waste irrigation + drainless drainage in combination with the application of straw into the soil in the amount of $4 \mathrm{t} \cdot \mathrm{ha}^{-1}$;

7. waste irrigation + drainless drainage in combination with subsoiling and the application of straw into the soil in the amount of $4 \mathrm{t} \cdot \mathrm{ha}^{-1}$;

8. wastes irrigation + drainless drainage in combination with loosening to a depth of $60 \mathrm{~cm}$ and the application of straw into the soil in an amount of $4 \mathrm{t} \cdot \mathrm{ha}^{-1}$.

The allocation of registration plots was systematic, and their size was $100 \mathrm{~m}^{2}$.

The drainless drains were trenches of 0.8-1.0 m depth. A $20 \mathrm{~cm}$ layer of straw or plant debris was laid at the bottom of the trenches. After that, the trenches were covered with excavated earth. The distances between the drainless drains were taken $10 \mathrm{~m}$ and they were across the previously laid drainage. After $5 \mathrm{~m}$, filter windows were arranged along the length of the drainless drain, using straw or crop residues for this purpose. The fall of the drains copied the surface and averaged 0.002.

The grassing of the experimental site was performed with the sowing of perennial grasses after agromeliorative practices in the autumn of 1998. The overgrassing was in the autumn of 2003. Cereal crops were cultivated at the experimental site in 2006-2008. Repeated grassing was carried out in the spring of 2009. Agromeliorative measures were repeated and straw was introduced before grassing of options 3 to 8 .

Manure irrigation was carried out based on an annual nitrogen rate of $280 \mathrm{~kg} \cdot \mathrm{ha}^{-1}$. If the moisturizing effect of the waste did not provide the required level of soil moisture, then additional wetting by natural water from accumulating reservoirs was carried out. Watering in the plots was prescribed in case of decrease in the soil moisture in the layer of $0.5 \mathrm{~m}$ to the level of $75 \%$ of minimum water capacity. Agrotechnics for growing grass and analytical research methods were generally accepted.

The research program included the studying of the soil moisture, water balance and the soil properties, the chemical composition of waste used for irrigation. The crop accounting was carried out by the method of continuous harvesting of plots. The obtained results were processed by methods of mathematical statistics. 
The soil of the experimental plot is sod-podzolic, slightly loamy, silty and characterized for this zone.

The research period covered years of different moisture and heat supply. So, 1999, 2002, 2010 and 2014 were dry and warm. In 2000, 2001, precipitation during the growing season fell more than normal, and in terms of heat these years were approaching normal. 2003, 2005 and 2009 were close in precipitation to normal. It was common to all vegetation periods that the precipitations were unevenly distributed.

\section{Results and discussion}

Regulation of the water regime in the irrigation system was carried out taking into account natural moistening by atmospheric precipitation, moisture reserves in the soil and a different combination of fertilizer, fertilizer-moisturizing and moisturizing watering (Table 1).

Table 1

Irrigation regime for perennial grasses during the research periods (1999-2005, 2009-2010 and 2014)

\begin{tabular}{|c|c|c|}
\hline $\begin{array}{l}\text { Years of the } \\
\text { research }\end{array}$ & $\begin{array}{c}\text { Dates of watering (numerator) and watering norms in } \mathbf{~ m m} \\
\text { (denominator) }\end{array}$ & $\begin{array}{l}\text { Irrigation } \\
\text { rates, mm }\end{array}$ \\
\hline 1999 & 26.IV/25; 21.V/25; 17.VI/25;14.VII/25;07.VIII/20. & 120 \\
\hline 2000 & 04.V/20; 14.VI/20; 19.VIII/19. & 59 \\
\hline 2001 & $06 . \mathrm{V} / 20 ; 16 . \mathrm{VI} / 20 ; 25 . \mathrm{VIII} / 23$. & 63 \\
\hline 2002 & 24.IV/18; 23.V/25; 21.VI/20; 19.VII/25; 07.VIII/20; 21.VIII/25. & 133 \\
\hline 2003 & $07 . \mathrm{V} / 20 ; 16 . \mathrm{VI} / 25 ; 25 . \mathrm{VII} / 25$. & 70 \\
\hline 2004 & 03.V/25; 14.VI/25; 23.VII/25; 08.IX/20. & 95 \\
\hline 2005 & 29.IV/25; 07.VII/25; 31.VIII/25. & 75 \\
\hline 2009 & $28 . \mathrm{IV} / 20 ; 18 \mathrm{~V} / 25 ; 04 . \mathrm{VII} / 25 ; 26 . \mathrm{VIII} / 20$ & 90 \\
\hline 2010 & 26.VIII/25; 04.VI/20; 20.VII/25; 05.VII/25; 22.VII/20. & 115 \\
\hline 2014 & 22.VI/25; 25.V/20; 03.VI/25; 25.VI/25; 18.VII/25; $10 . \mathrm{IX} / 20$. & 135 \\
\hline
\end{tabular}

The analysis of the obtained data showed that depending on the moisture supply of the growing season during utilizing livestock wastes by a nitrogen rate of $280 \mathrm{~kg} \cdot \mathrm{ha}^{-1}$ and creating an optimal water regime in the root layer of the soil, from three to six waterings with irrigation rates of $18-25 \mathrm{~mm}$ were required. At the same time, the irrigation norms ranged from $59-135 \mathrm{~mm}$. The average water consumption of perennial grasses over the years of the research was $403.5 \mathrm{~mm}$ in the control without irrigation, $488.7 \mathrm{~mm}$ during watering by waste, $489.9 \mathrm{~mm}$ during watering by waste against the background of drainless drainage, and 491.0-493.3 m during watering by waste against the background of drainless drainage combined with agromeliorative practices. The greatest total water consumption of perennial grasses was noted in the variant of watering by livestock runoff against the background of drainless drainage combined with deep loosening and the application of straw. Compared to the control without irrigation, the total water consumption of perennial grasses was on average more by $85.2-90.3 \mathrm{~mm}$ or $21.1-22.4 \%$ in the irrigated variants. The water consumption of perennial grasses obtained by the calculation method for the sum of air humidity deficits using bioclimatic coefficients on average over the years of the research was $496.3 \mathrm{~mm}$ and differed from the actual water consumption obtained in the experiment by no more than 5-10\%.

Observations of the water regime of the soil indicate that even in years with normal and excessive natural moisture, additional moistening of perennial grasses is required, due to the uneven precipitation and heat distribution. The short-term waterlogging of the soil that occurs in certain periods is explained by the need to utilize the annual volume of waste regardless of the weather conditions. At the same time, the noted overmoistening did not adversely affect the development of grasses and did not lead to a decrease in their productivity.

In dry and warm vegetation periods of 1999, 2002, 2010 and 2014 due to fertilizer and fertilizermoisturizing irrigation, optimal soil moisture was maintained during the growing season, without causing moistening of the upper soil layer of $50 \mathrm{~cm}$. 
Fluctuations of irrigation norms in years were caused by the variability of the meteorological conditions.

The results of the soil water balance calculation over the years of the research showed that during utilizing livestock stocks in irrigation fields, the water consumption of perennial grasses, on average over the years of the research, was $403.5 \mathrm{~mm}$ in the control without irrigation, $488.7 \mathrm{~mm}$ during watering by waste, $489.9 \mathrm{~mm}$ during watering by waste against the background of drainless drainage and 491.0-493.3 $\mathrm{mm}$ during watering by waste against the background of drainless drainage in combination with agromeliorative measures. The greatest total water consumption of perennial grasses was noted in the variant of watering by livestock waste against the background of drainless drainage combined with deep loosening and the application of straw. Compared with the control (without irrigation) in the irrigated varieties the total water consumption of perennial grasses was on average by 85.2-90.3 $\mathrm{mm}$ or $21.1-22.4 \%$ more.

The moisture deficit was significant in the dry years in the control option and ranged from 122.2 to $157.9 \mathrm{~mm}(1999,2002,2004,2010,2014)$. On irrigated options, the water regime was mainly maintained within optimal limits. In the years with sufficient natural moisture (2000, 2001, 2003, and 2009) in all options generally during the growing season there was a slight excess of moisture, including with irrigation. However, this did not affect the development of perennial grasses, since precipitations were uneven, and watering during these periods was of a fertilizing nature and their norms were determined based on the application of the required amount of biogenic elements.

In general, the agromeliorative practices contributed to the optimal redistribution of moisture in the meter layer of soil and its effective use. Holding agromeliorative practices in combination with drainless drainage made it possible to regulate the productive moisture reserves in optimal limits and to use them more efficiently, especially during carrying out deep loosening in combination with straw.

Excess water in certain periods and years led to the formation of surface runoff. When watering by livestock waste at a rate of $20-25 \mathrm{~mm}$, puddles were observed on the surface of the field during wet periods that indicated the presence of surface runoff within individual options of the irrigated field (Table 2).

Table 2

Area of microdepressions filled with surface runoff, $\mathbf{m}^{2} \cdot \mathrm{ha}^{-1}$

\begin{tabular}{|c|c|c|c|c|c|c|c|c|}
\hline \multirow{2}{*}{ Years } & \multicolumn{9}{|c|}{ Options of experiment } \\
\cline { 2 - 9 } & $\mathbf{1}$ & $\mathbf{2}$ & $\mathbf{3}$ & $\mathbf{4}$ & $\mathbf{5}$ & $\mathbf{6}$ & $\mathbf{7}$ & $\mathbf{8}$ \\
\hline 1999 & 12.3 & 33.0 & 28.4 & 22.1 & 20.8 & 18.9 & 18.6 & 18.7 \\
\hline 2000 & 16.1 & 35.8 & 30.3 & 26.4 & 22.1 & 20.8 & 19.9 & 19.6 \\
\hline 2001 & 10.5 & 31.7 & 26.2 & 23.2 & 21.7 & 19.3 & 18.2 & 18.0 \\
\hline Average & 13.0 & 33.5 & 28.3 & 23.9 & 21.5 & 19.7 & 18.9 & 18.8 \\
\hline $\begin{array}{c}\text { Reduction, \% } \\
\text { compared to } \\
\text { 2nd option }\end{array}$ & - & - & 15.5 & 28.6 & 35.8 & 41.5 & 43.6 & 44.2 \\
\hline
\end{tabular}

In irrigated options, the total area of flooded depressions on average over the years of the research ranged from 18.8 to $35.8 \mathrm{~m}^{2} \cdot \mathrm{ha}^{-1}$.

The use of agromeliorative measures and drainless drainage reduced surface runoff. In the options with agroameliorative treatment, the area of microdepressions filled with water was by $15.5-44.2 \%$ less in comparison to the $2^{\text {nd }}$ option, where the treatment was not carried out.

As a result of the research, it was found that the reliability of the specialized water rotation and amelioration system increases significantly during conduction of agromeliorative measures in combination with drainless drainage. Irrigation of areas where drainless drainage was laid through 10 $\mathrm{m}$, in combination with agromeliorative practices (subsoiling by $30 \mathrm{~cm}$ and loosening to a depth of 60 $\mathrm{cm}$ ) and the application of straw in the amount of $4 \mathrm{t} \cdot \mathrm{ha}^{-1}$ provided the most favorable regulation of the water regime of sod-podzolic soil. In all studied options, the main factor of variability of the water regime of sod-podzolic soil is atmospheric precipitation. In the control without irrigation the specific gravity of useful precipitations in the total water consumption of perennial grasses averaged $78.4 \%$ over 10 years, and the consumption of moisture reserves from the soil was $21.6 \%$. In the irrigated 
options, the share of used precipitations was $64.1-64.7 \%$ of the total water consumption of perennial grasses. Watering by waste of the pig-breeding complex in combination with clean water made up 19.2-19.4\% of the total water consumption, and the average share of soil moisture reserves was 16.1$16.5 \%$.

The use of agromeliorative measures for tillage and drainless drainage had a beneficial effect on the hydrological regime of the irrigated area. The area of microdepressions filled with water in the options with agromeliorative treatment decreased by 15.5-44.2\%, including in variants of drainless drainage in combination with loosening by $35.8 \%$, with straw application - by $41.5 \%$, with subsoiling and straw application - by $43.6 \%$, with loosening and straw application - by $44.2 \%$ [4].

By combining drainless drainage with subsoiling, watering by livestock waste made the yield of perennial grasses increased. The most significant increase in the yield of perennial grasses was achieved by fertilizing watering and sowing straw into the soil. The maximum yield increases in the experiment were obtained against the background of drainless drainage in combination with deep loosening and the application of straw into the loosened upper soil layers (option 8). Here, the yield was higher by $8.5 \%$ than in the $2^{\text {nd }}$ option.

The introduction of a significant amount of nutrients into the soil with livestock waste contributed not only to an increase in the yield of perennial grasses, but also to a significant change in the qualitative indicators. An analysis of the quality of the feed mass of hay showed that digestible protein in grams per $1 \mathrm{~kg}$ of feed was 29.5-32.8, fiber - 70.1-82.3, crude fat -7.1-8.9, sugar - 14.1-17.8, and carotene $-35.1-39.4 \mathrm{mg} \cdot \mathrm{kg}^{-1}$ of feed. The feed contained phosphorus $0.74-1.01 \mathrm{~g} \cdot \mathrm{kg}^{-1}$, and calcium 2.7-3.4 $\mathrm{g} \cdot \mathrm{kg}^{-1}$. At the same time, there was no significant effect of drainless drainage and agromeliorative measures on the quality of the dry mass of grasses.

Irrigation by waste increased the nitrate content in the dry mass of perennial grasses. At the same time, no significant differences were found between the experimental options. Despite a slight increase in the nitrate content during fertilizer irrigation, the value of this indicator did not exceed the MAC. This was due to the fact that watering was carried out strictly according to the regulations, ensuring compliance with the doses and timing of watering.

Calculations of economic efficiency showed that due to agromeliorative treatment and drainless drainage against the background of fertilizer irrigation, the feed production increased and amounted to 0.44-0.79 tons of feed units from 1 hectare.

\section{Conclusions}

1. On specialized water rotation and amelioration systems designed for the disposal of livestock waste, it is recommended to provide a drainless drainage device with a distance between drains 10 $\mathrm{m}$ and a depth of $0.8 \mathrm{~m}$ and with laying straw or crop residues of a layer of $20 \mathrm{~cm}$ at the bottom of trenches. Filter windows from straw should be provided through every $5 \mathrm{~m}$ along the length of the trench for better absorption of drains. The estimated service life of trenchless drainage is 8 years.

2. To improve the water regime and agrophysical properties of soil during disposal of livestock waste in irrigation fields, it is recommended to carry out deep loosening $(60 \mathrm{~cm})$ and straw application at the rate of $4.0 \mathrm{t} \cdot \mathrm{ha}^{-1}$. The effectiveness of agromeliorative practices has been observed for 5-6 years.

3. Against the background of drainless drainage combined with agromeliorative measures and the application of straw, it is recommended to carry out watering by livestock waste fractionally with a total norm of $280 \mathrm{~kg} \cdot \mathrm{ha}^{-1}$ for nitrogen. Depending on the meteorological conditions of the growing season, the number of watering varies from 3-6 with a watering rate of $18-25 \mathrm{~mm}$ and an irrigation rate of $75-135 \mathrm{~mm}$.

\section{References}

[1] Zhelyazko V. I. Ecological and meliorative basics of land irrigation by waste of pig-breeding complexes. Gorki, 2003.168 p. (In Russian).

[2] Ovtsov L.P. Ecological assessment of sewage and manure sludge in agrocenosis. Moscow State University, 2000. 318 p. (In Russian). 
[3] Tivo P. F. Quality of grass feed in the area of action of livestock complexes. NTI and the market, 1996. vol. 9. pp. 26-29.

[4] Tivo P.F., Brezgunov V.S., Kutko S.M. Water protection bioengineering facilities. Agricultural reporter, 2001. vol. 5. pp. 22-23.

[5] Metz R. Fundamentals of the effective use of wastewater in agriculture of the GDR. Use of wastewater for irrigation of crops: Collection of scientific papers. Volgograd, 1990. pp. 15-20. (In Russian).

[6] Zakkour P.D., Gaterell M.R., Griffin P. Anaerobic treatment of domestic wastewater in temperate climates: treatment plant modelling with economic considerations. Water Research, 2001. vol. 35(17). pp. 4137-4149.

[7] Ternes T.A., Bonerz M., Herrmann N. Irrigation of treated wastewater in braunschweig, Germany: an option to remove pharmaceuticals and musk fragrances. Chemosphere, 2007. vol. 66 (5). pp. 894-904.

[8] Islam M.S., Rahman L., Alam M.S. Correlation and path coefficient analysis in fat and fatty acids of rapeseed and mustard. Bangladesh J. agr. Res, 2009. vol. 34(2). pp. 247-253.

[9] Mooers H.D., Alexander Jr. E.C. Contribution of spray irrigation of wastewater to groundwater contamination in the karst of southeastern Minnesota, USA. Hydrogeology Journal, 1994, vol. 2(1), pp. 34-44.

[10] Lubello C., Gori R., Nicese F.P., Ferrini F. Municipal-treated wastewater reuse for plant nurseries irrigation. Water Research, 2004. vol. 38(12). pp. 2939-2947.

[11] Skousen, J., Clinger C. Sewage sludge land application program in west Virginia, 1993. vol. 48(2) pp. $145-151$. 